\title{
Moderately-differentiated neuroendocrine carcinoma of the larynx: a case report and literature review
}

\author{
Rak neuroendokrynny krtani o średnim stopniu zróżnicowania: \\ opis przypadku i przegląd piśmiennictwa
}

\author{
'Department of Otorhinolaryngology, Hospital Sultanah Aminah, Malaysia \\ 2 Department of Pathology, Hospital Sultanah Aminah, Malaysia \\ ${ }^{3}$ Department of Otorhinolaryngology - Head \& Neck Surgery, School of Medical Sciences, Universiti Sains Malaysia, Kubang Kerian, Kelantan, Malaysia \\ Correspondence: Chok Tong Khaw, Department of Otorhinolaryngology, Hospital Sultanah Aminah, Jalan Abu Bakar, 80100 Johor Bahru, Johor, Malaysia, tel:: 60138181510, e-mail: choktong87@gmail.com
}

Abstract Laryngeal neuroendocrine carcinoma is a rare tumour of the larynx, accounting for only about $1 \%$ of all primary laryngeal tumours. Laryngeal neuroendocrine carcinomas are classified as well-, moderate- and poorly-differentiated neuroendocrine carcinoma. The differentiating features of each category include nuclear atypia, mitotic rate and presence or absence of necrosis. Immunochemistry stains also help in diagnosing laryngeal neuroendocrine carcinoma. In this article, we present a case report of moderately-differentiated neuroendocrine carcinoma of the larynx in a 57-year-old man who presented with neck pain and dysphagia persisting for one month. There is no standard treatment regimen for laryngeal neuroendocrine carcinoma. However, due to the poor prognosis for moderately-differentiated laryngeal neuroendocrine carcinomas, we advocate aggressive and prompt treatment and surveillance PET-CT scan 6 months postoperatively.

Keywords: immunohistochemistry (IHC), larynx, neuroendocrine carcinoma (NEC), laryngectomy

Streszczenie Rak neuroendokrynny krtani to rzadki nowotwór, stanowiący jedynie 1\% przypadków guzów pierwotnych o takim umiejscowieniu. Nowotwory te klasyfikuje się jako dobrze, średnio i słabo zróżnicowane. Cechami różnicującymi te kategorie są atypia jądrowa, wskaźnik mitotyczny oraz obecność/brak martwicy. W diagnostyce raka neuroendokrynnego krtani pomocne jest również badanie immunohistochemiczne. W pracy przedstawiono przypadek średnio zróżnicowanego raka neuroendokrynnego krtani u 57-letniego mężczyzny z utrzymującymi się od miesiąca objawami pod postacią bólu szyi i dysfagii. Obecnie nie ma standardowego schematu leczenia tego nowotworu. Niemniej jednak z uwagi na złe rokowanie w przypadku raka neuroendokrynnego krtani o średnim stopniu zróżnicowania autorzy pracy zalecają bezzwłoczne i agresywne leczenie oraz kontrolne badanie PET-TK sześć miesięcy po zabiegu.

Słowa kluczowe: badanie immunohistochemiczne (IHC), krtań, rak neuroendokrynny (NEC), laryngektomia 


\section{INTRODUCTION}

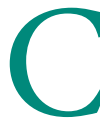

ancers of the larynx accounted for approximately $1.1 \%$ of all human neoplasms worldwide in 2012, according to the World Cancer Research Fund International ${ }^{(1)}$. Neuroendocrine carcinomas (NEC) in the head and neck region are rare. Most commonly, they originate from the gastrointestinal system or the bronchial system. However, in the head and neck region, NECs most commonly affect the laryn $\mathrm{x}^{(2)}$. Laryngeal neuroendocrine carcinoma (LNEC) falls into the category of heterogeneous neoplasm, the most common non-squamous tumours of this organ, representing about $1 \%$ of all primary laryngeal tumours ${ }^{(3)}$. The diagnosis is based on the histological characteristics of a neuroendocrine architecture or immunohistochemical (IHC) confirmation of neuroendocrine differentiation. Histological diagnosis is the most important step leading to appropriate management, and the prognosis varies depending on the histological type, tumour size and evidence of metastasis.

\section{CASE REPORT}

A 57-year-old Chinese man, a chronic smoker, presented with left neck swelling and pain persisting for one month and associated with dysphagia. He denied loss of weight and loss of appetite and had no family history of malignancy. On examination, there was a left level II non-tender $2 \times 2 \mathrm{~cm}$ neck swelling. Flexible nasopharyngolaryngoscopy

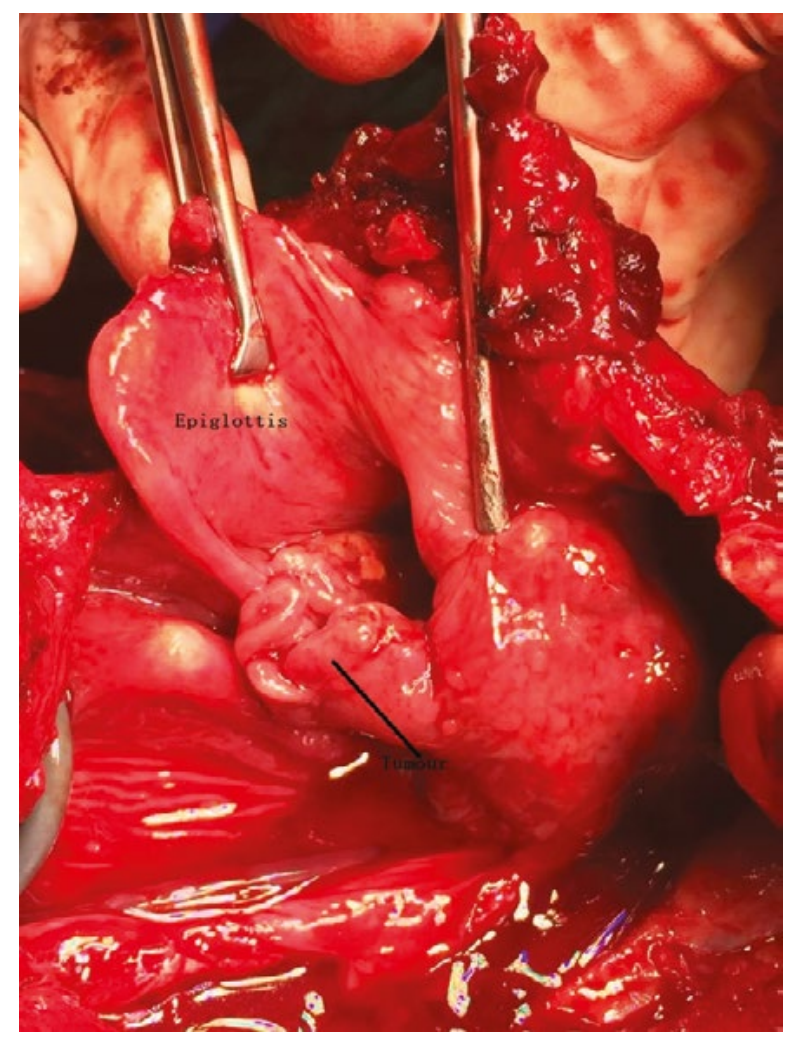

Fig. 1. Intraoperative finding of tumour at the left aryepiglottic fold

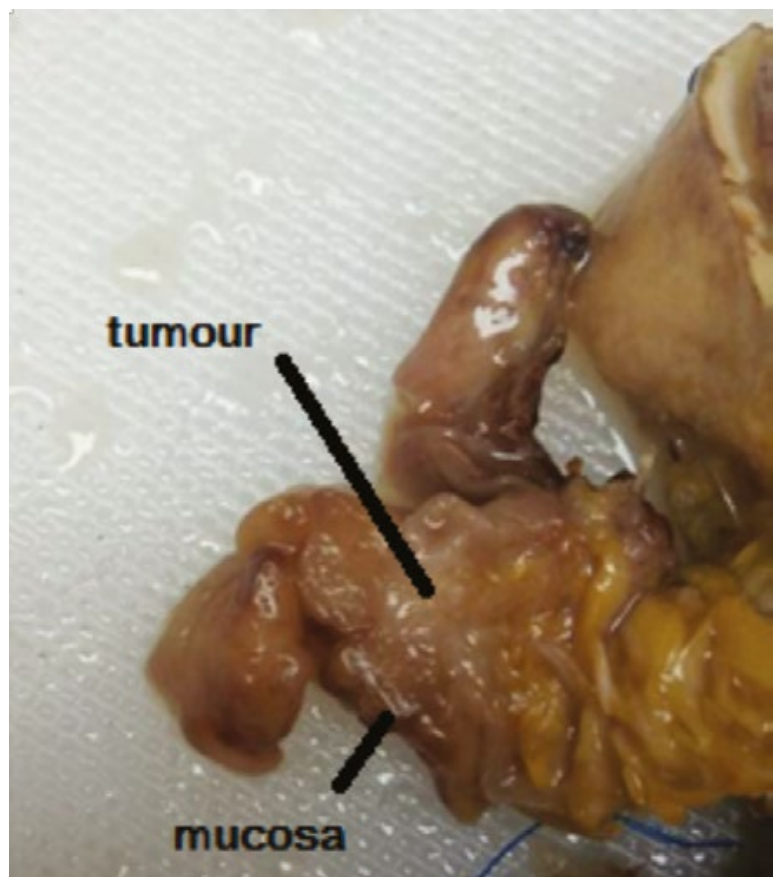

Fig. 2. Submucosal location of tumour

showed a mass at the left arytenoids, left aryepiglottic fold and left false cord.

Contrast-enhanced computed tomography of the neck, thorax, abdomen and pelvis showed effacement of left pyriform sinus with ill-defined hypodensities at the supraglottic level superior to the vocal cord. There were multiple enlarged left level II and III cervical nodes.

Direct laryngoscopy and biopsy were performed and the histopathological findings confirmed the diagnosis of neuroendocrine carcinoma.

Total laryngectomy and left radical neck dissection were performed promptly (Fig. 1).

Gross examination of the specimen showed a $20 \times 20$ $\times 12 \mathrm{~mm}$ polypoidal, submucosal tumour with focal ulceration involving the supraglottis, left side of the aryepiglottic fold, false vocal cord, ventricle and true vocal cord (Fig. 2). Microscopic examination showed tumour predominantly located within the left supraglottis, including the aryepiglottic fold, extending downward to involve the false cord, vestibule and true vocal cord. The subglottis was not involved. The tumour also extended radially, involving the vocal cord muscle and focally into the paraglottic space. The tumour was arranged in cords, trabeculae and sheets with some glandular pattern. The tumour cells exhibited rounded nuclei with stippled "salt and pepper" chromatin and inconspicuous nucleoli. Mitotic activity was about 6/10 HPF (Olympus CX31). Immunohistochemical studies showed tumour positivity for pancytokeratin, synaptophysin, chromogranin, TTF-1 (weak) and calcitonin (Figs. 3-4). Metastatic carcinoma was present in 4 out of 15 lymph nodes which were isolated from the neck dissection specimen of this patient. 


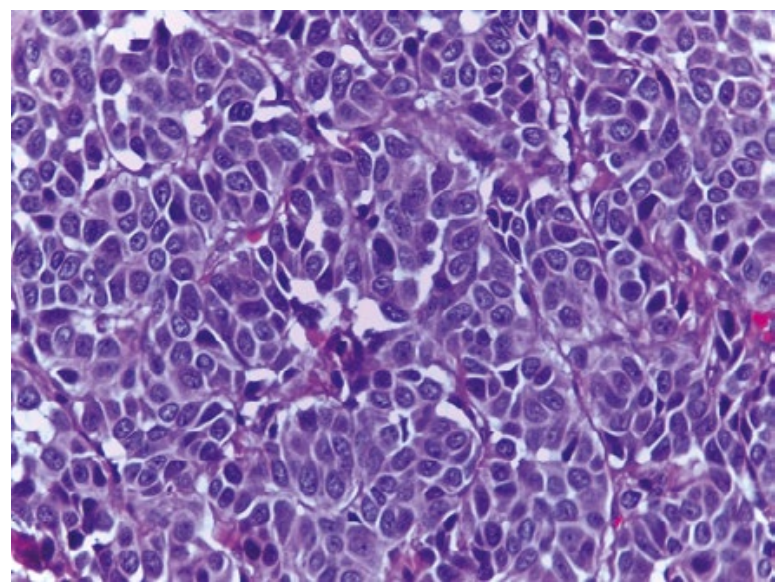

Fig. 3. Haematoxylin and eosin $-\times 40$

He was staged as T3N2bM0 and referred to an oncologist for adjuvant radiotherapy. The patient was on monthly follow up post total laryngectomy and a PET-CT FDG was performed 9 months postoperatively, showing several new small lung nodules of less than $1 \mathrm{~cm}$. However, one year post total laryngectomy the patient was still well and leading an active lifestyle with no respiratory symptoms or evidence of recurrence. He was under oncologist monitoring for further management.

\section{DISCUSSION}

LNECs are commonly seen in elderly men. These carcinomas are also highly associated with smoking with reported rates of $73-94 \%^{(2)}$. Our patient was also a chronic smoker. Clinical features vary and may include dysphagia, hoarseness, odynophagia, dyspnoea and haemoptysis ${ }^{(4)}$. Instead of complaining about voice symptoms, our patient presented with left neck swelling associated with dysphagia. Only upon performing flexible laryngoscopy were we able to visualize a mass arising from the left arytenoids, the aryepiglottic fold and the left false cord. Even though squamous cell carcinoma is the most common laryngeal carcinoma, surgeons should always bear in mind the possibility of NECs, which make up about $1 \%$ of laryngeal carcinomas, as it is the most common non-squamous tumour of laryn $\mathrm{x}^{(3,5)}$. NECs most commonly affect the supraglottic regions with reported incidence of 60 to $96 \%^{(2,6)}$. In this case however, there was also true cord involvement upon histological examination of the larynx.

Neuroendocrine tumours of the larynx can be divided into two types, i.e. epithelial (carcinoma) and neural tumours (paraganglioma) $^{(2)}$. The 2005 World Health Organization (WHO) classification distinguished four types of NECs: (i) typical carcinoid; (ii) atypical carcinoid; (iii) small-cell carcinoma, neuroendocrine type and (iv) combined smallcell carcinoma, neuroendocrine type with non-smallcell carcinoma. However, in the latest 2017 WHO update, LNECs were classified as well-, moderate- and poorly-

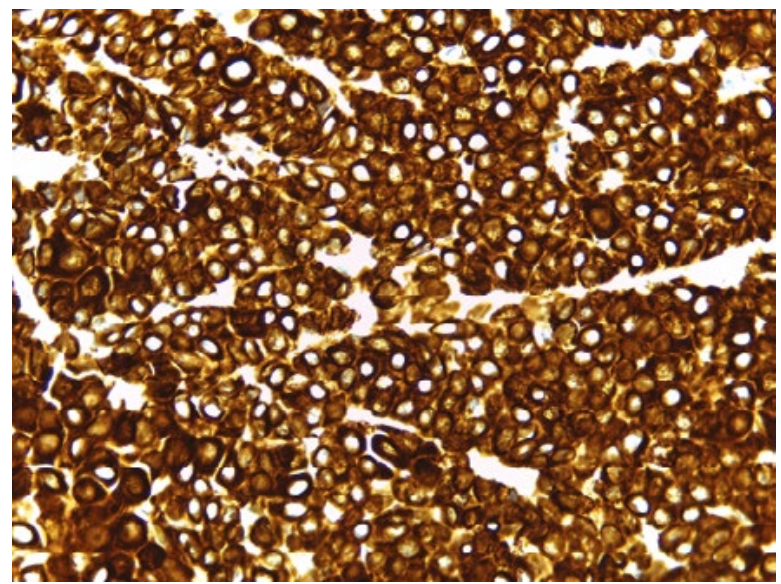

Fig. 4. Pancytokeratin $-\times 40$

divided into small cell NEC (SmCNEC) and large cell NEC (LCNEC). LCNEC, which was associated in the 2005 WHO edition with atypical carcinoid (moderately-differentiated NEC grade II in the new classification), has now been transferred into the group of poorly-differentiated NEC, grade III, displaying a specific morphology and poorer prognosis ${ }^{(2)}$. The differentiating features of each category include nuclear atypia, mitotic rate and the presence or absence of necrosis; unlike NEC of other sites, whose graining includes the Ki67 proliferative index. Until 2017, publications on LNECs were still using the previous WHO classification, which can be very confusing for surgeons. However, this case report will be based on the new WHO classification of LNECs in the aim of increasing the awareness of this new classification system.

As for immunohistochemistry, these tumours are positive for cytokeratins and at least one neuroendocrine marker (e.g. synaptophysin, chromogranin or CD56), while TTF-1 is variably positive. Differential diagnosis should exclude the possibility of a metastasis from the lung. These tumours are also frequently positive for calcitonin, which creates a potential diagnostic pitfall, particularly in the case of lymph node metastasis, where the tumour can be mistaken for medullary thyroid carcinoma (MTC). Useful distinguishing features include immunostaining for TTF-1. Whereby it is diffusely and strongly positive in MTC, but it is either negative or only weakly and focally positive in primary LNEC. MTC will also have an associated elevated serum calcitonin, but not in primary LNEC. Immunohistochemical studies of this case showed tumour positivity for pancytokeratin, synaptophysin, chromogranin, TTF-1 (weak) and calcitonin which favour NEC.

In terms of prognosis, the 5-year disease-specific survival was $100 \%$ for well-differentiated NEC, 53\% for moderately-differentiated NEC, 19\% for SmCNEC and 15\% for LCNEC $^{(2)}$. There were various treatments employed for the NECs with various outcomes. Our patient with moderately-differentiated NEC with neck nodes metastasis was well at one-year follow up after total laryngectomy with left radical neck dissection and radiotherapy. In contrast, a patient 
reported by Chung et al., who was similar to our case in terms of histological subtype and metastasis to 4 lymph nodes, but underwent only supraglottic partial laryngectomy and left radical neck dissection with postoperative radiotherapy, died of cancer at six months due to multiple spinal metastasis ${ }^{(5)}$. Kasantikul et al. described a woman with moderately-differentiated LNEC with bilateral enlarged neck nodes and lumbar vertebrae metastasis who died six months post total laryngectomy and neck dissection without adjuvant therapy ${ }^{(7)}$. These cases support the fact that moderately-differentiated LNECs are aggressive and will present with early metastasis which might or might not be picked up by initial radiological imaging, but would likely be picked up by surveillance imaging.

In our case, there were suspicious lung nodules in this patient on repeated PET-CT scan nine months postoperatively. Another case recently published in Japan by Hanakawa et al. describes a 79-year-old man with mixed right laryngeal carcinoma (atypical carcinoid and squamous cell carcinoma) with right fixed vocal cord and two positive nodes in the right neck. The patient underwent total laryngectomy, neck dissection and postoperative irradiation and he was well 4 years post treatment ${ }^{(8)}$.

A retrospective study of 11 patients with moderately-differentiated LNECs in 2005 summarised that this malignancy is aggressive and frequently metastasizes, and recommended a combination of surgery, radiotherapy and chemotherapy ${ }^{(9)}$. In contrast, another meta-analysis concluded that atypical carcinoid does not respond well to radiotherapy ${ }^{(10)}$.

With advancement in diagnostic tools and radiotherapy techniques, as well as based on the current literature, we suggest total laryngectomy followed by adjuvant radiotherapy for the treatment of moderately-differentiated LNECs. Also, there should be a surveillance imaging 6 months after the surgery to detect recurrence or distant metastasis. Further studies or trials are needed to establish the role of adjuvant chemotherapy to curb metastases.

\section{CONCLUSION}

Histological diagnosis based on the criteria mentioned above and immunohistochemistry staining is of utmost importance for the management of laryngeal tumours. Moderately-differentiated LNECs are aggressive and often have distant metastasis. Prompt and aggressive treatment is advocated in moderately-differentiated subtype, as seen in this case where total laryngectomy was performed, followed by radiation therapy to achieve better prognosis. We also suggest performing surveillance PET-CT scan six months postoperatively to evaluate metastases and implement early treatment to further improve the prognosis.

\section{Conflict of interest}

The authors do not declare any financial or personal links with other persons or organisations that might adversely affect the content of the publication or claim any right to the publication.

\section{References}

1. Worldwide cancer data. World Cancer Research Fund. 2018. Available from: https://www.wcrf.org/dietandcancer/cancertrends/worldwide-cancer-data [cited: 12 April 2018].

2. Gale N, Poljak M, Zidar N: Update from the $4^{\text {th }}$ edition of the World Health Organization classification of head and neck tumours: what is new in the 2017 WHO Blue Book for tumours of the hypopharynx, larynx, trachea and parapharyngeal space. Head Neck Pathol 2017; 11: 23-32.

3. Zhu Y, Gao L, Meng Y et al.: Laryngeal neuroendocrine carcinomas: a retrospective study of 14 cases. Biomed Res Int 2015; 2015: 832194.

4. Marfatia H, Priya R, Sathe NU et al.: Laryngeal neuroendocrine tumour: a rare case report and review of literature. Sch J Med Case Rep 2016; 4: 479-483.

5. Chung EJ, Baek SK, Kwon SY et al.: Moderately differentiated neuroendocrine carcinoma of the larynx. Clin Exp Otorhinolaryngol 2008; 1: 217-220.

6. Lin HW, Bhattacharyya N: Staging and survival analysis for nonsquamous cell carcinomas of the larynx. Laryngoscope 2008; 118: 1003-1013.

7. Kasantikul V, Keelawat S, Maneesri S et al.: Moderately differentiated neuroendocrine carcinoma (atypical carcinoid) of the larynx. J Med Assoc Thai 1997; 80: 396-401.

8. Hanakawa H, Inokuchi I, Ayada $\mathrm{N}$ et al.: [Laryngeal atypical carcinoid combined with squamous cell carcinoma: a case report]. Nihon Jibiinkoka Gakkai Kaiho 2015; 118: 34-39.

9. Gillenwater A, Lewin J, Roberts D et al:: Moderately differentiated neuroendocrine carcinoma (atypical carcinoid) of the larynx: a clinically aggressive tumor. Laryngoscope 2005; 115: 1191-1195.

10. van der Laan TP, Plaat BEC, van der Laan BFAM et al.: Clinical recommendations on the treatment of neuroendocrine carcinoma of the larynx: a meta-analysis of 436 reported cases. Head Neck 2015; 37: 707-715. 